\title{
Neonatal Care Education during Pregnancy Using Videos on the iPosyandu Application
}

\author{
Fedri Ruluwedrata Rinawan, ${ }^{1,2}$ Ilma Dina Arrahmah, ${ }^{3}$ Didah Didah, ${ }^{1}$ Nelly Dameria \\ Sinaga, ${ }^{4}$ Ari Indra Susanti, ${ }^{1,2}$ Rima Kusumah Dewi, ${ }^{5}$ Atriany Nilam Sari ${ }^{6}$ \\ ${ }^{1}$ Department of Public Health, Faculty of Medicine, Universitas Padjadjaran, Sumedang, Indonesia, \\ ${ }^{2}$ Center for Health Systems Studies and Health Personnel Education Innovation, Faculty of Medicine, \\ Universitas Padjadjaran, Bandung, Indonesia, ${ }^{3}$ Midwifery Diploma Study Program, Politeknik Kesehatan \\ Kementerian Kesehatan Bandung, Sumedang, Indonesia, ${ }^{4}$ Midwifery Master Study Program, Faculty of Medicine, \\ Universitas Padjadjaran, Bandung, Indonesia, ${ }^{5}$ Makassar Regional General Hospital, Makassar, Indonesia, \\ ${ }^{6}$ Midwifery Study Program, Faculty of Medicine, Universitas Sebelas Maret, Surakarta, Indonesia
}

\begin{abstract}
Indonesia Demographic and Health Survey (IDHS) 2017 shows that the neonatal mortality rate (NMR) in Indonesia was 15 per 1,000 live births. A decrease in NMR to 12 per 1,00o live births can reduce the infant mortality rate (IMR). Purwakarta regency in 2019 ranked 14 out of 27 regencies and cities that contribute to the NMR in West Java. This research analyzes the knowledge of pregnant women about neonatal care before and after being given a combination of video animation and demonstration on the iPosyandu Parents application. The research method used was quantitative with one group pretest-posttest design, an interventional study without a control group. The sample size was 60 pregnant women in their third trimester. Samples that met the criteria were taken by purposive sampling technique and according to the midwife's instructions at the Pasawahan Public Health Center, Purwakarta regency. This research was conducted in May 2020. The knowledge data were collected using a questionnaire that was translated from previous studies. The questionnaire topic groups were adapted from the government's Maternal and Child Health book. The results showed differences in knowledge before and after being given health education using audiovisual media in 7 topic groups. They comprised general information on neonatal care, early breastfeeding initiation, breastfeeding, keeping babies warm, umbilical cord care, schedule of neonatal visits, and immunization. However, there was no difference in one topic group, namely the newborn danger critical signs.
\end{abstract}

Keywords: Animation, combination, demonstration, neonatal, nursing

\section{Edukasi selama Kehamilan tentang Perawatan Neonatus Menggunakan Video pada Aplikasi iPosyandu}

\begin{abstract}
Abstrak
Angka kematian neonatus (AKN) menurut Survei Demografi dan Kesehatan Indonesia (SDKI) tahun 2017 di Indonesia adalah 15 per 1.0oo lahir hidup. Penurunan AKN hingga 12 per 1.ooo kelahiran hidup dapat menekan angka kematian bayi (AKB). Kabupaten Purwakarta pada tahun 2019 menempati urutan ke-14 dari 27 kabupaten dan kota penyumbang AKN di Jawa Barat. Tujuan penelitian ini menganalisis pengetahuan ibu hamil mengenai perawatan neonatus sebelum dan sesudah diberikan video kombinasi animasi dan demonstrasi pada aplikasi iPosyandu Orangtua. Metode penelitian yang digunakan adalah kuantitatif dengan desain one grup pretestposttest yang merupakan penelitian intervensional tanpa kelompok kontrol. Besar sampel dalam penelitian ini adalah 60 ibu hamil trimester III. Sampel yang memenuhi kriteria diambil dengan teknik purposive sampling sesuai dengan arahan dari bidan Puskesmas Pasawahan Kabupaten Purwakarta. Penelitian ini dilakukan pada bulan Mei 2020. Pengumpulan data pengetahuan dilakukan dengan menggunakan kuesioner yang diterjemahkan dari penelitian sebelumnya. Kelompok topik kuesionernya disesuaikan dengan buku Kesehatan Ibu dan Anak (KIA) dari pemerintah. Hasil penelitian menunjukkan bahwa terdapat perbedaan pengetahuan sebelum dan sesudah diberikan pendidikan kesehatan menggunakan media audiovisual pada 7 kelompok topik. Topik tersebut terdiri atas informasi umum perawatan neonatus, inisiasi menyusui dini (IMD), pemberian ASI, menjaga bayi tetap hangat, perawatan tali pusat, jadwal kunjungan neonatal, dan imunisasi. Akan tetapi, kelompok mengenai tanda bahaya bayi baru lahir tidak terdapat perbedaan.
\end{abstract}

Kata kunci: Animasi, kombinasi, neonatus, peragaan, perawatan

Received: 3 September 2021; Revised: 22 December 2021; Accepted: 30 December 2021; Published: 31 December 2021

Correspondence: Fedri Ruluwedrata Rinawan, dr., M.Sc.P.H., Ph.D. Department of Public Health, Faculty of Medicine, Universitas Padjajaran. Kampus Jatinangor. Jln. Ir. Soekarno km 21, Jatinangor, Sumedang 45363, West Java, Indonesia. E-mail: f.rinawan@unpad.ac.id 


\section{Introduction}

In the Indonesian Demographic and Health Survey (IDHS) 2017, the neonatal mortality rate (NMR) was 15 per 1,00o live births. The Ministry of Health of Republic of Indonesia targets the IMR to drop to 12 per 1,000 live births, thus reducing the infant mortality rate (IMR). According to the health profile of West Java, the Purwakarta regency was ranked $14^{\text {th }}$ out of 27 regencies and cities that contributed to NMR in West Java, with 77 NMR cases in 2019. The NMR, IMR, and the infant and child mortality rate (ICMR) can be reduced by having an integrated service post (pos pelayanan terpadu, posyandu). Posyandu is a form of community-sourced effort that facilitates the people to obtain health services and information. Among the benefits is that pregnant women can have easier access to information about health, and mothers, babies, and toddlers can easily receive health services. In terms of quantity, the number of posyandu is around 3-4 posyandu per village. However, several quality problems were found, including mothers not utilizing posyandu. One indication of the use of health services by the community is the active participation of the community at the posyandu..$^{1,2}$

This utilization will increase public exposure to information from posyandu, including details on neonatal mortality prevention. When the community does not use this, they will lack information about neonatal care. One way to fill the gap between the needs regarding a person's knowledge and abilities is by education that activates the five senses, mainly the senses of hearing and sight. Good educational media can stimulate feelings, attention, thoughts, abilities, and learning skills. They can encourage knowledge change and a more effective and efficient learning process. Time and learning intensity are also essential factors in the learning process. ${ }^{3,4}$ Information technology under user-friendly needs can be one of the leading alternative solutions..$^{5,6}$

Since 2017, the Universitas Padjadjaran Lecturer Competency Research team has been developing information technology for posyandu called the iPosyandu mobile application. The application is made for cadres and parents with the same database. The iPosyandu application dedicated explicitly to parents is called iPosyandu Orang Tua (parents). This application makes it easier for parents to monitor the growth and development of their children. Their data have been recorded by cadres on the iPosyandu application, specifically for cadres. ${ }^{7}$ In addition, this application contains educational material for parents, including pregnant women, in preparing neonatal babies. ${ }^{8}$ This application features educational videos (Figure 1) intended to create a more focused learning atmosphere than learning on chat applications such as WhatsApp, LINE, and Telegram. This research continues Susanti et al.'s study (2019), which assessed the parents' knowledge that they had not used videos in the iPosyandu application. ${ }^{9}$ The advantage of video media is that it presents the object as a whole and conveys a real message. It is perfect for stimulating or motivating the learning process. Videos can reduce learning boredom, especially with other learning techniques such as lectures and screened case discussions. This combination will increase memory retention or retention of learning objects in learners. ${ }^{10}$

The videos in this research were made based on input from pregnant women to involve humans in the video and combine them with animation. This educational video, especially for pregnant women, which is the focus of the research, was intended to prepare pregnant women by providing knowledge about neonatal care. Therefore, the

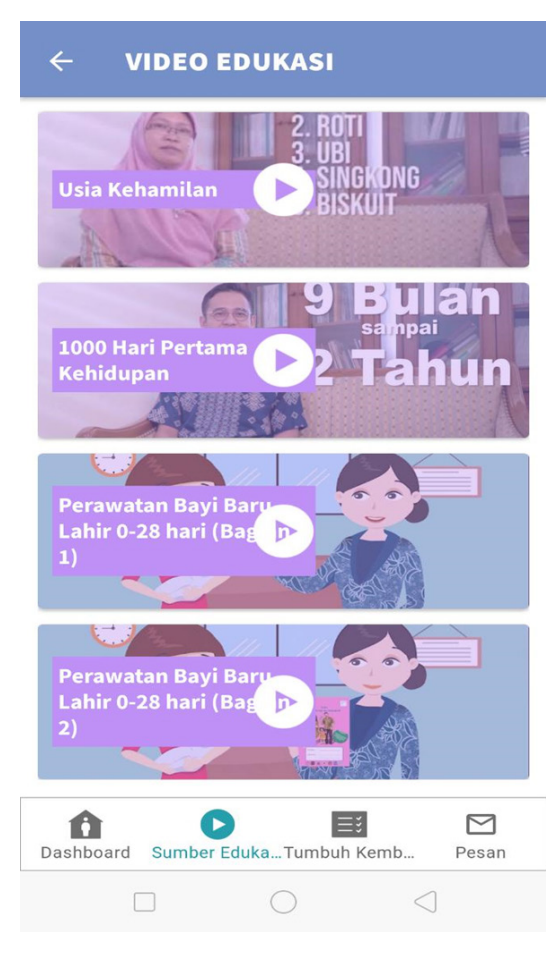

Figure 1 Educational Video Menu 
purpose of this research was to identify thirdtrimester pregnant women's knowledge and the effectiveness of the iPosyandu Orang Tua application platform with the combination videos about neonatal care in educating the mothers.

\section{Methods}

This research employs a quantitative method with the one-group pretest-posttest design, an interventional study without a control group. This research was conducted in the jurisdiction of Pasawahan Community Health Center, Purwakarta regency. The reason for choosing this area was because the need for an application that could assist cadres and parents in monitoring toddlers has been identified since 2016. As a result, the iPosyandu application was created in 2017. In this application, cadres have registered the data of parents and children so that parents can access them using the iPosyandu Orang Tua application, including the educational videos. The number of samples in this research was 60 third trimester pregnant women based on calculations with $\alpha=0.05$ (two-tailed), $\beta=0.2$, and standardized effect size $=0.59 .{ }^{11}$ This research used a purposive sampling technique with selected samples that met the inclusion criteria. The criteria are pregnant women in the third trimester that owned and were able to operate an Android-based smartphone and WhatsApp, had an internet data plan, and had downloaded the iPosyandu Orangtua Application from the Google Play Store. This research was conducted in May 2020, and research permits were obtained from three agencies, namely the National and Political Unity Agency, the Health Office, and the Pasawahan Community Health Center. The Ethics Committee of Universitas Padjadjaran Bandung is based on the ethical license 1139/ UN6.KEP/EC/2020 approved this research.

The knowledge data collection was carried out using a questionnaire translated from previous studies. ${ }^{12-14}$ The questionnaire topic group was adapted to the Maternal and Child Health book from the government and was presented in a Google Form. The next step was to collect data on third-trimester pregnant women at the Pasawahan Community Health Center assisted by the coordinating midwife. After that, the WhatsApp group was created so that 60 respondents of third-trimester pregnant women could join. The research agreement was started by explaining to the respondent about this research, namely the benefits, research procedures, and disadvantages of the study. After the respondents agreed with the informed consent sheet, they immediately filled in the pretest sheet and answered neonatal care questions. The respondents then downloaded the iPosyandu Orang Tua application from the Google Play Store. At the bottom of the initial display, the respondents can see an educational video icon (Figure 1). Then to watch the video, the respondents were given instructions to click on the educational video icon and choose a neonatal care video. The video was made based on input from pregnant women to make humans provide explanations and animations. When finished, the respondents immediately filled out the posttest questionnaire sheet.

Data were analyzed using univariate analysis to see the characteristics of the respondents. Bivariate analysis using the Wilcoxon difference test using the IBM SPSS version 26 software was carried out because the data was not normally distributed (Kolmogorov-Smirnov obtained a $\mathrm{p}$ value<0.05). Cohen's effect size was calculated by dividing the $\mathrm{Z}$ score (standardized test statistical score, which is the output of SPSS in calculating the Wilcoxon difference test) with $\sqrt{ } \mathrm{n}$ (number of respondents). The effect size with a value between $0.1-0.29$ is categorized as small, $0.3-0.49$ as a medium, and $\geq 0.5$ as large..$^{15,16}$

\section{Results}

The research subjects' characteristics were divided into age, education, and occupation. The description of the characteristics of thirdtrimester pregnant women in Pasawahan district, Purwakarta regency, using the frequency distribution, is presented in Table 1.

Table 1 describes the age category of respondents with most respondents were aged $20-35$ years old as many as 50 people $(84 \%)$ and the least being aged $\geq 35$ years, as many as two people (3\%). On the characteristics of education, most of the respondents were in the secondary education category as many as 37 people (62\%) and the least in the higher education category, 9 people (15\%). For occupation, most respondents did not work, 43 people (72\%), and 17 people had work $(28 \%)$.

Table 2 shows the differences in knowledge about neonatal care before and after video education. Based on Table 2, some highlights emerge based on the effect size of the educational videos on the knowledge groups. The largest 
Table 1 Frequency Distribution of the Trimester III Pregnant Women Characteristics

\begin{tabular}{lc}
\hline Characteristics & $\mathbf{n = 6 0}(\%)$ \\
\hline Age (years) & \\
$\quad<20$ & $8(13)$ \\
$20-35$ & $50(84)$ \\
$\quad \geq 35$ & $2(3)$ \\
Education & \\
$\quad$ Primary (elementary, junior & $14(23)$ \\
$\quad$ high school) & \\
$\quad$ Secondary (high school/ & $37(62)$ \\
$\quad$ vocational high school) & \\
Higher (higher education & $9(15)$ \\
$\quad$ institution) & \\
Occupation & \\
$\quad$ Working & $17(28)$ \\
$\quad$ Not working & $43(72)$ \\
\hline
\end{tabular}

one is breastfeeding, followed by umbilical cord care, neonatal visit schedule, early breastfeeding initiation, keeping baby warm (medium effect), general knowledge of neonatal care, and immunization (small effect). Nonetheless, the educational videos did not affect newborn danger signs knowledge.

\section{Discussion}

Based on the literature, health education effectively increases knowledge and skills. The use of audiovisual media is effective in conveying messages to the public. ${ }^{17-20}$ It is reinforced by the latest research (2019), which stated that providing knowledge with a complete sensing process will give better results ${ }^{21}$ and using educational videos can effectively change mothers' knowledge. ${ }^{22}$ This case can occur because the information and learning experiences gained by watching videos will be absorbed by $30 \%$. When added with demonstration, the information absorbed will be 50\%. Suppose it is further strengthened by the participation of the mothers in conducting simulations. In that case, it will stimulate the senses of hearing and sight so that the results obtained are maximized (90\%). ${ }^{18,23}$ Other research made videos only and showed significant results regarding mothers' knowledge and attitudes; however, their effects were not calculated. ${ }^{24,25}$ The demonstration in videos with non-animated roleplaying (by humans) shows the complete sensing process accompanied by roleplaying, which gives better results than lectures and videos only. ${ }^{21}$

The combination of animation and nonanimation, as in this research, can further activate the five senses to gain effective results. The development of video media in a 2020 research entitled "Neonatal Care" was designed based on the results of qualitative interview analysis. The research stated that the health education videos must follow the community's needs, consisting of animated characters and real demonstrations. In addition, the video must be packaged in a clear and interesting storyline and under the characters depicted. Animated characters are displayed for information on neonatal care that is too graphic to display, such as breastfeeding, early initiation of breastfeeding, and the Kangaroo method. Nonvulgar information, such as general neonatal care, keeping baby warm, umbilical cord care, neonatal visit schedules, newborn danger signs, and immunizations, are presented in the form

Table 2 Differences in Knowledge of Neonatal Care

\begin{tabular}{|c|c|c|c|c|}
\hline \multirow[b]{2}{*}{ Knowledge Group } & \multicolumn{2}{|c|}{ Mean } & \multirow[b]{2}{*}{$\mathbf{p}$} & \multirow[b]{2}{*}{ Effect Size } \\
\hline & $\begin{array}{c}\begin{array}{c}\text { Pretest } \\
n=60\end{array} \\
\text { nat }\end{array}$ & $\begin{array}{c}\text { Posttest } \\
\mathbf{n}=60\end{array}$ & & \\
\hline General knowledge of neonatal care & 0.87 & 0.97 & 0.034 & 0.27 \\
\hline Early initiation of breastfeeding & 2.58 & 2.80 & 0.005 & 0.36 \\
\hline Breastfeeding & 3.75 & $4 \cdot 32$ & 0.000 & 0.52 \\
\hline Keeping baby warm & 0.67 & 0.97 & 0.005 & 0.36 \\
\hline Umbilical cord care & 2.50 & 2.78 & 0.001 & 0.43 \\
\hline Neonatal visit schedule & 2.10 & 2.54 & 0.001 & 0.42 \\
\hline Newborn danger signs & 2.13 & 2.18 & 0.527 & 0.08 \\
\hline Immunization & 1.70 & 1.83 & 0.033 & 0.27 \\
\hline
\end{tabular}


of concrete demonstrations. These contents are also in line with other research on neonatal care parameters such as skin-to-skin contact between the baby and the mother, first bath time, instruments used to cut the umbilical cord, early initiation of breastfeeding, and general information regarding exclusive breastfeeding. ${ }^{12}$ This combination of animation and real demonstration (Figure 2) gave significant results with an effectiveness range between 0.27-0.52 (o.1-0.29: small, 0.3-0.49: medium, and 0.5: large) in almost all content groups. ${ }^{15,16}$

The content in the research video consists of one content group with considerable effect, namely breastfeeding; 4 content groups that had medium effects: (1) early initiation of breastfeeding, (2) keeping the baby warm, (3) umbilical cord care, and (4) schedule of neonatal visits; 2 groups of contents with small effect: general knowledge and immunization; and one with minimal and insignificant effect (newborn danger signs). Breastfeeding in this study gave the most substantial-effectiveness value compared to the other eight groups. Previous research showed significant differences in knowledge and attitudes between before and after health education with multimedia methods about breastfeeding and breastfeeding. However, they did not mention the effectiveness of the method. ${ }^{26}$ The instruction regarding breastfeeding has an effectiveness value of 0.52 , which is in the strong category, ${ }^{15,16}$ the strongest among other groups. Information on breastfeeding was given in animation only because it contains sensitive matters. However, previous research suggested that animation can still provide significant changes. ${ }^{24,25}$ Early breastfeeding initiation is crucial $^{27}$-education on keeping babies warm shows a medium effect.
However, the medium effect is still good, and if the videos were to be watched again, they could still increase knowledge. Keeping the baby warm is not easy to learn because it contains several methods. Types of care regarding keeping the baby warm include bathing the baby properly, changing diapers and clothes when wet, and not putting the baby to sleep in cold and windy places. In addition, it is essential to wear head caps, socks, gloves, and warm clothes by not swaddling the baby tightly. Another step is to dry the baby properly. ${ }^{28}$ As for keeping the baby warm for babies with low birth weight (LBW) conditions, the Kangaroo method, with the principle of skinto-skin contact, for example, heat transfer from mother to the baby so that the baby stays warm, calm, and sleeps well. In addition, this method can also improve the mother's relationship with her baby.

Increasing knowledge about proper and correct umbilical cord care is crucial. ${ }^{29}$ In this research, the educational video intervention had a medium effect. Giving examples of good practice through video demonstrations is in line with previous research to increase the knowledge and expertise of mothers in umbilical cord care. ${ }^{29,30}$ The schedule of neonatal or newborn visits (0-28 days) provides a corridor for knowledge diffusion. This schedule is one of the main foundations that regulates and supports meeting times for providing knowledge about neonatal care from the midwife to the mother. ${ }^{31}$ General knowledge of neonatal care needs to be obtained since the third trimester of pregnancy, including indicators of normal weight from birth. Education to prevent LBW is very important. ${ }^{32}$ In addition, immunization arrangements can be integrated with visit schedules and educational
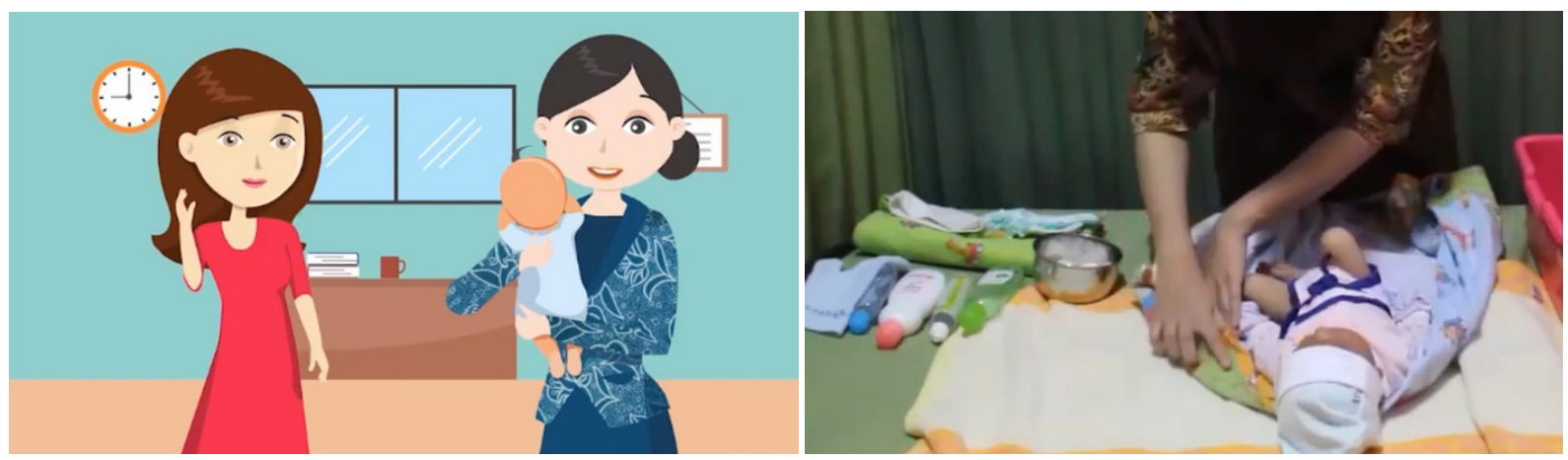

Figure 2 Combination of Animation and Real-life Demonstration of Neonatal Care Videos in the iPosyandu Application 
information related to future immunizations. ${ }^{33,34}$

The newborn danger signs are education with the topic group with a minimal and insignificant effect. This case occurred because the mothers did not easily comprehend the material. ${ }^{35}$ Humans have two types of memory, namely short-term memory (working memory) and long-term memory. ${ }^{36}$ The memory can store initial information ranging from several up to 30 seconds, and it can take several hours to process information consciously. Then, the information can be repeated or further processed to strengthen the memory. ${ }^{37}$ Especially for mothers with strong memories who already have basic knowledge, the material given in the video was understandable. Therefore watching the video was mainly a repetition. Repetition does not result in the addition of new knowledge content. In this research, the mothers had already known enough before receiving the video intervention (mean pretest score $=2.13$ from 3 questionnaire questions in the group). The mothers probably had read the content from a book. The video content on the newborn danger signs was adopted from the government's Mother and Child Health handbook. ${ }^{28}$

The video duration was shortened to approximately 10 minutes to overcome the problem of boredom when viewing video content. Therefore, the educational videos were divided into two video parts. The ideal video duration to prevent boredom is about 5 to 20 minutes. ${ }^{38}$ The videos shown in the iPosyandu Orang Tua application are about child development, nutrition for children, gestational age, and the first 1,000 days of life. In conducting online learning using an application, the availability of the internet network is one of the obstacles. However, the iPosyandu Orang Tua application benefited from easier access and focused on repeating learning online. The benefits outweighed the obstacles. In Indonesia, the existing internet network was $78 \%$ in 2016, and since 2019 there has been a plan to continue expanding so that it can cover all of Indonesia. ${ }^{39}$ The obstacle that arises is the ability of individuals to purchase data plans. It can be overcome by providing a Wi-Fi network in each village. $^{7}$

\section{Conclusions}

Neonatal care knowledge provided through health education during pregnancy using video media in the iPosyandu application can contain people giving demonstrations and animations. With this combination, knowledge of neonatal care can provide effects ranging from medium to large. However, the combination can have no impact in pre and post-evaluation assessments on a minority of topics for two reasons: complex material or good prior knowledge.

\section{Conflict of Interest}

The authors have no conflict of interest in writing this article.

\section{Acknowledgments}

The authors would like to thank the Pasawahan Community Health Center, Purwakarta Regency Health Office, the respondents in this research, the Indonesia Endowment Fund for Education, abbreviated LPDP (Lembaga Pengelola Dana Pendidikan), the Ministry of Finance, and the Kreasi Insani Persada Foundation.

\section{References}

1. Purnanto NT, Purhadi, Nanda MS. Studi deskriptif tingkat pengetahuan ibu tentang posyandu di Desa Katekan UPT Puskesmas Brati Kabupaten Grobogan. TSCNers. 2017;2(2):8-13.

2. Busyaeri A, Udin T, Zaenudin A. Pengaruh penggunaan video pembelajaran terhadap peningkatan hasil belajar mapel IPA di MIN Kroya Cirebon. Al Ibtida. 2016;3(1):116-37.

3. Notoadmodjo S. Ilmu perilaku kesehatan. Jakarta: Rineka Cipta; 2012.

4. Aeni N, Yuhandini DS. Pengaruh pendidikan kesehatan dengan media video dan metode demonstrasi terhadap pengetahuan SADARI. Jurnal Care. 2018;6(2):162-74.

5. Nurdianti D, Kurniawati A. Pengetahuan ibu hamil mengenai perawatan masa nifas dan bayi baru lahir di wilayah kerja Puskesmas Kersanegara Kota Tasikmalaya tahun 2020. In: LPPM Universitas Muhammadiyah Purwokerto, editor. Prosiding Seminar Nasional Hasil Penelitian dan Pengabdian pada Masyarakat V; 2020; Purwokerto. Purwokerto: LPPM Universitas Muhammadiyah Purwokerto; 2020. p. 3225.

6. Feroz A, Perveen S, Aftab W. Role of mHealth 
applications for improving antenatal and postnatal care in low and middle income countries: a systematic review. BMC Health Serv Res. 2017;17(1):704.

7. Rinawan FR, SusantiAI, Amelia I, Ardisasmita MN, Widarti, Dewi RK, et al. Understanding mobile application development and implementation for monitoring posyandu data in Indonesia: a 3-year hybrid action study to build "a bridge" from the community to the national scale. BMC Public Health. 2021;21(1):1024.

8. Widarti, Rinawan FR, Susanti AI, Fitri HN. Perbedaan pengetahuan kader posyandu sebelum dan sesudah dilakukan pelatihan penggunaan aplikasi iPosyandu. J Pengabdi Pengembangan Masy. 2018;1(2):143-50.

9. Susanti AI, Rinawan FR, Amelia I. Mothers knowledge and perception of toddler growth monitoring using iPosyandu application. GMHC. 2019;7(2):93-9.

10. Purwanti B. Pengembangan media video pembelajaran matematika dengan model assure. J Kebijakan Pengembangan Pendidikan. 2015;3(1):42-7.

11. Bisallah CI, Rampal L, Lye MS, Sidik SM, Ibrahim N, Iliyasu Z, et al. Effectiveness of health education intervention in improving knowledge, attitude, and practices regarding tuberculosis among HIV patients in General Hospital Minna, Nigeria-a randomized control trial. PLoS One. 2018;13(2):e0192276.

12. Memon J, Holakouie-Naieni K, Majdzadeh R, Yekaninejad MS, Garmaroudi G, Raza $\mathrm{O}$, et al. Knowledge, attitude, and practice among mothers about newborn care in Sindh, Pakistan. BMC Pregnancy Childbirth. 2019;19(1):329.

13. Majumder S, Najnin Z, Ahmed S, Bhuiyan SU. Knowledge and attitude of essential newborn care among postnatal mothers in Bangladesh. J Health Res. 2018;32(6):4408.

14. Mandal M, Ghosh A. Evaluation of awareness of neonatal care practices among postnatal mothers in a tertiary care hospital. Clin Obstet Gynecol Reprod Med. 2016;2(5):1-5.

15. Pallant J. SPSS survival manual: a step by step guide to data analysis using SPSS program. $6^{\text {th }}$ Edition. London: McGraw-Hill Education; 2016.

16. Field A. Discovering statistics using IBM SPSS statistics. $5^{\text {th }}$ Edition. Thousand Oaks:
SAGE Publications; 2018.

17. Afriyani LD, Salafas E. Efektivitas media promosi kesehatan ASI perah terhadap peningkatan pengetahuan ibu bekerja untuk memberikan ASI eksklusif. Siklus. 2019;8(1):60-6.

18. Zakaria F, Rono H, Kartini F. Pengaruh pendidikan kesehatan dengan media audiovisual terhadap pengetahuan dan sikap ibu tentang inisiasi menyusu dini. JKK. 2017;13(2):128-40.

19. Kusumaningrum PR, Elsera C. Upaya meningkatkan kemampuan ibu dalam perawatan neonatus. Motorik. 2018;13(27):143-50.

20. Triguno Y, Supahar, Purnami LA. Pengembangan media video untuk meningkatkan pengetahuan dan sikap ibu tentang tumbuh kembang anak di wilayah kerja Puskesmas Jagoi Babang Kalimantan Barat. Midwinerslion. 2020;5(1):184-94.

21. Panjaitan AA, Widagdo L, Prabamurti PN. Intervensi ceramah video dan ceramah diskusi terhadap pengetahuan dan sikap remaja dalam kesehatan reproduksi. J Promosi Kesehat Indones. 2019;14(1):40-52.

22. Mulyani I, Fitriana NF. Pengaruh pemberian edukasi menggunakan audio visual (video) pada ibu terhadap pengetahuan penanganan tersedak balita. J Keperawatan Muhammadiyah Bengkulu. 2020;8(2):8793 .

23. Syamsidar S, Maruf, Hustim R. Pembelajaran fisika berbasis cone of experience Edgar Dale pada materi elastisitas dan fluida statis. JPF. 2018;6(1):1-12.

24. Febriani CA, Nuryani DD, Elviyanti D. Efektifitas pemanfaatan media gambar bergerak dan video animasi terhadap peningkatan pengetahuan dan sikap ibu tentang gizi seimbang pada balita. J Kesehat. 2019;10(2):181-6.

25. Widyawati SA, Afandi A, Wahyuni S. Peningkatan pengetahuan ibu hamil dan menyusui melalui pengembangan model dan media animasi pemberian ASI eksklusif pada bayi. J Ilmiah Permas. 2020;10(1):103-8.

26. Hapitria P, Padmawati R. Efektifitas pendidikan kesehatan melalui multimedia dan tatap muka terhadap pengetahuan dan sikap ibu hamil tentang ASI dan menyusui. Care. 2017;5(2):156-67.

27. Sukmawati, Stang, Bustan N. Pengaruh 
edukasi terhadap pengetahuan dan sikap ibu hamil tentang inisiasi menyusui dini (IMD) di wilayah kerja Puskesmas Parangloe Kabupaten Gowa. JKMM. 2018;1(1):7-13.

28. Kementerian Kesehatan Republik Indonesia. Buku kesehatan ibu dan anak. 2020 Prints [Internet]. Jakarta: Kementerian Kesehatan Republik Indonesia; 2020 [cited 2020 July 5]. Available from: https://kesga.kemkes. go.id/assets/file/pedoman/BUKU\%20 KIA\%2OTAHUN\%202020\%20BAGIAN\%20 ANAK.pdf.

29. Hatniah, Sundari S. Tingkat pengetahuan ibu hamil trimester III tentang perawatan tali pusat di Puskesmas Srandankan Bantul Yogyakarta. JIK. 2019;5(2):172-81.

30. Metha JM. Gambaran perawatan tali pusat bayi baru lahir terhadap lamanya waktu pelepasan tali pusat di Pekanbaru. JPK. 2015;4(2):146-50.

31. Handayani S, Wulandari L. Hubungan pengetahuan dan sikap ibu terhadap kunjungan neonatal. Babul Ilmi. 2019;11(1):35-43.

32. Rosela K, Taviane E, Alestari RO. Pengaruh pendidikan kesehatan terhadap tingkat pengetahuan ibu hamil dalam pencegahan terjadinya kelahiran bayi berat badan lahir rendah (BBLR) di wilayah kerja UPTD Puskesmas Pahandut Palangka Raya.
Dinamika Kesehatan. 2016;7(2):60-7.

33. Simanjuntak SM, Nurnisa I. Peningkatan pengetahuan dan sikap ibu tentang imunisasi dengan pendekatan promosi kesehatan tentang imunisasi dasar. MKK. 2019;2(1):38-52.

34. MulyaniS, ShafiraNNA, Haris A. Pengetahuan ibu tentang kelengkapan imunisasi dasar pada bayi. JMJ. 2018;6(1):45-55.

35. Nigatu SG, Worku AG, Dadi AF. Level of mother's knowledge about neonatal danger signs and associated factors in North West of Ethiopia: a community based study. BMC Res Notes. 2015;8:309.

36. Atkitson RL, Atkitson RC, Hilgard ER. Pengantar psikologi. $8^{\text {th }}$ Edition. Jakarta: Erlangga; 2011.

37. Lusiawati I. Pengembangan otak dan optimalisasi sumber daya manusia. TEDC. 2017;11(2):162-71.

38. Nurdin E, Ma'aruf A, Amir Z, Risnawati, Noviarni, Azmi MP. Pemanfaatan video pembelajaran berbasis Geogebra untuk meningkatkan kemampuan pemahaman konsep matematis siswa SMK. JRPM. 2019;6(1):87-98.

39. Puspitasari L, Ishii K. Digital divides and mobile internet in Indonesia: impact of smartphones. Telemat Inform. 2016;33(2):472-83. 